pollution of the New England rivers, the lumberer and manufacturer have ruined the cod-fishery of that locality by destroying the anadromous fishes which attracted the cod thither ; so that thus the "fish oil" and "fish guano" manufacturers, who are now enriching themselves, not only at the expense of the herring and menhaden, but of the other species which depend on these for food, will speedily, if unchecked, increase the depletion of the northern waters of the United States; thus increasing the value of the concession made by the Treaty of Washington, and rendering it still more important that laws should not only be made, but enforced, for the prevention of a similar depletion of the (at present) bighly productive fishing-grounds of the Dominion.

William B. CARPENTER

\section{THE GEOLOGY OF LONDON}

A L'THOUGH the British Government have undertaken the geological survey of the country, yet the valuable results obtained by this survey are unfortunately allowed to remain almost unknown to the general public. A complete set of the publications of the geological survey costs, we believe, something like $130 l$, and is, of course, quite out of the reach of all but great libraries and wealthy public institutions, and no authorised reductions of the maps have as yet been published. It is much to be regretted, too, that the illiberal parsimony displayed in some branches of our public service is most conspicuous of all in that scientific department of it, where its effects prove most injurious. While the publications of the American geological surveys are distributed in foreign countries with an open-handed liberality worthy of a great government, and the courtesy of the chiefs of those surveys, Dr. Hayden and $\mathrm{Mr}$. Clarence King, is well known to everyone-it is notorious that the directors of our own survey are placed in the painful position of having to refuse to acknowledge the just claims of the largest and most important scientific institutions of their own and other countries. The directors of our national surveys are the more to be pitied, inasmuch as the position of grudging parsimony in which they are placed contrasts so strikingly with that course of wise and judicious liberality in making known the results of their labours which the officers of the scientific departments of the United States and some other countries are permitted to pursue.

Another matter calling for serious consideration on the part of those who manage the publication of the results of these national surveys, is the exorbitant prices so often charged for the maps and memoirs. We know not whether it be the result of mismanagement or something worse, but it is a fact that it would seem to cost this Government department three or four times as much to produce a map or memoir as a private firm would require to accomplish the same work. Surely these publications not being handicapped with the charges of authorship, ought to be alike marvels of cheapness and models of excellence, yet how very different is the fact! For an unmounted one-inch map of the district around London the public is charged thirty shillings; for very moderate-sized volumes printed on inferior paper and having the general aspect of mean blue-books put into cloth covers, the sum demanded is two pounds; and recently the geological survey has surpassed even itself by issuing a small paper-covered pamphlet at the price of seventeen shillings!

None suffer so much from the effects of this unwise parsimony and obvious mismanagement as the officers of the survey itself. Those among their number who are engaged in active scientific work see the results of their

- Stanford's Geological Map of London and its Suburbs. 'The Geology compiled from the Maps and other Works of the Geological Survey of Eng land and Wales by James B. Jordan. Size, 76 inches by $6{ }_{5}$. Scale, 6 inches to a mile. (London: Edward Stanford, 2878 .) labours, after long delays and many vexations, placed before the public in an almost inaccessible form; and they are too often disappointed and discouraged by finding that they do not receive the credit which their persevering labours so well deserve. Possibly, as has frequently happened, an amateur observer working independently, and untrammelled by the chains of officialism, is able to forestall their results, by publishing in a scientific journal the most important of their conclusions. Have not the directors of these surveys yet learnt that the day is gone by, when scientific writings can with impunity be delayed for years in the press?

Fortunately the evils to which we have directed attention in the foregoing paragraphs have a tendency to work their own cure. Thus, though the English Government have not followed the wise example of Austria in publishing chromo-lithographed reductions of the larger maps, the director-general and the directors of the branch surveys have produced privately useful maps on a reduced scale of the areas of which they respectively have charge. Objectionable as it may seem in principle that Government officials should issue as private speculations these results of their labours, it is certainly better that they should be allowed so to do, than that the public should be altogether deprived of such important publications.

The map of which the appearance has prompted the foregoing remarks, is another example of private enterprise being allowed to take in hand what we might fairly expect to be accomplished by a national institution. At the Loan Exhibition of Scientific Apparatus, in 1876 , a MS. map of the geology of the district around London, drawn on the scale of six inches to the mile, attracted much attention. Since that time this map, with a well-constructed model of the same area, has formed one of the attractions of the admirable museum at Jermyn Street. In this instance the wise course was adopted of publishing a cheap "Guide to the Geology of London," which was drawn up by $\mathrm{Mr}$. Whitaker, one of the most active and efficient officers of the survey, and a geologist whose researches are well known to scientific men beyond its limits. We believe that this excellent little book has had the large circulation it so well deserves; and it is certainly much better calculated to attract the attention of the general public to the important work that is being carried on by the Geological Survey than some of the more ponderous. volumes, of which only a few copies are sold at very high prices in each year.

But valuable as the information on this six-inch map clearly was to a large section of the public, its information has been allowed to remain unpublished, and now Mr. Stanford has had to step in to supply the deficiency. Taking advantage of his excellent and well-known library map of London, and securing the services of Mr. James B. Jordan, who has bad so much experience in work of this character, he has issued the geological information in question in a very convenient form. The map embraces all the area from Finchley on the north to Beclenham on the south, and from Blackheatb on the east to Shepherd's Bush on the west. The subdivisions of the superficial deposits are not so numerous as might possibly have been desired on a map of this large scale, and the work shows too evident traces of having been compiled from a variety of different sources, some of the areas having been carefully surveyed on the six-inch scale, while others are only enlargements of the one-inch map. Nevertheless, with all these drawbacks the map furnishes information not to be obtained from any other published source, and it will supply a want that was beginning to be extensively felt among the ever-growing population of the metropolis.

The colours of the map are exceedingly well chosen and tastefully combined. Until it is superseded by an authoritative Government publication on the same scale, it is sure to bave an extensive circulation. 